\title{
The dominant narrative of the New Zealand-China Free Trade Agreement: Peripheral evidence, presumptive tilt and business realities
}

\author{
Antje Fiedler ${ }^{a *}$
}

\section{Benjamin Fath ${ }^{a}$}

\section{Hugh Whittaker ${ }^{b}$}

${ }^{a}$ Graduate School of Management, University of Auckland, Auckland, New Zealand;

${ }^{b}$ School of Interdisciplinary Area Studies, University of Oxford, Oxford, UK;

*corresponding author: Antje Fiedler; Graduate School of Management; The University of Auckland; 12 Grafton Rd; 1142 Auckland, New Zealand; a.fiedler@ auckland.ac.nz

Word count (excluding references, table): 8048

Author biographies

D Hugh Whittaker is Professor of the Japanese Economy and Business at the School of Interdisciplinary Area Studies, University of Oxford, and a Research Fellow (and former Director) of the New Zealand Asia Institute, University of Auckland. His research interests include entrepreneurship, innovation management and comparative development in East Asia.

Antje Fiedler is a Senior Lecturer in Management at the Graduate School of Management, University of Auckland. Her research interests include institutions and institutional change, and small business strategy and internationalisation.

Benjamin P Fath is a Senior Lecturer in Management at the Graduate School of Management, University of Auckland. His research interests lie in the study of innovation, growth and internationalisation of SMEs.

Funding:

"This work was supported by the The University of Auckland Business School Faculty Research Development Fund". 


\section{The dominant narrative of the New Zealand-China Free Trade Agreement: Peripheral evidence, presumptive tilt and business realities}

New Zealand (NZ) was the first developed country to sign a free trade agreement with China. Afterwards, the NZ government crafted a narrative to encourage businesses to pursue opportunities there and in emerging Asia more generally to enact the enabling institutional change. Our study shows neoliberal free-trade rhetoric matched and thus likely confirmed businesses' opportunity perceptions but often mismatched their capabilities and thus interests. Businesses sampled predictably lacked scale, scope and other resources to realise the opportunities they perceived. We argue government communications tilted businesses towards the simplifying presumption that substantial opportunities lay within fairly easy grasp. As a result, over-enactment in entering the Chinese market followed. We identify the construct of 'peripheral evidence' as propping up presumptive tilt here and generally - irrelevant but widely observable facts or well-accepted predictions and opinion inappropriately shifted to centre-stage. Such centring discourages critical discourse and displaces properly central considerations - here the fundamental obstacles of size, scale and resources. Our study contributes to constructivist institutionalism by showing the mechanisms and tangible risks of uncritical pro-enactment discourse after formal trade liberalisation.

Keywords: enabling institutional change; constructivist institutionalism;

industrial policy; free trade agreement; Asia; China; New Zealand; firm strategy; trade liberalisation; enactment. 


\section{Introduction}

With varying degrees of enthusiasm, governments have opened domestic markets to international competition, shifting macroeconomic interventions towards trade liberalisation to stimulate innovation (Baldwin and Forslid 2000) and economic growth (Pavcnik 2002), even though the effects on individual firms are uncertain. This brings enabling, rather than constraining, institutional change to the fore. Existing institutionalist literature investigates the role of discourse in legitimising trade liberalisation in advance of enabling changes to formal institutions. Studies show neoliberal free-trade ideas are resilient in policy-making discourse (Siles-Brügge 2011), although trade discourse is evolving unevenly (Morin and Carta 2014, Bollen et al. 2016). While neoliberal discourse has enthusiastically reinforced free trade as a prerequisite of economic growth, researchers have noted problematic underpinning assumptions (De Ville and Orbie 2014), suggesting that the underlying neoliberal trade narrative is contestable. In particular trade liberalisation's effects on SMEs are poorly understood (OECD 1997).

Specifically, 'constructivist' or 'discursive' institutionalism highlights the communicative and cognitive elements in dominant narratives as a cornerstone of institutional change. It emphasises argumentative discourse in building a rationale for change and mobilising actors (Hay and Rosamond 2002, Martin 2015). Following Schmidt, we define discourse as 'whatever public actors say to one another and the society at large in efforts to generate and legitimise policy change' (2003: 129). Further, Schmidt (2008) distinguishes between coordinative discourse among policymakers to coordinate their ideas, and communicative discourse to communicate their ideas to the public. 
Gaps exist. Notably, how pro-trade liberalisation communicative discourse relates to the achievable realities and interests of the trading businesses, including SMEs, encouraged to enact it, is unclear (Boräng and Naurin 2015). Whilst in Eckhardt and Poletti's (2016) study import-dependent European firms promoted trade liberalisation, generally most, especially small, businesses will not have lobbied for liberalisation. Yet generally too, to take effect and induce the promised innovation, competitiveness and growth, enabling liberalisation requires businesses to internalise free-trade rationales and enact the trading opportunities enabled (Cornelissen et al. 2015). And to induce this sustainably and benefit firms in the long-term, the opportunities they enact must be, and stay, realistic for them. To date this process has received little empirical attention.

We address this gap through qualitative research into the New Zealand (NZ) government's narrative around free trade agreements (FTAs) - particularly during a renewed push for enactment after the signing of the NZ-China FTA (NZCFTA) in 2008 - and how that narrative aligns or misaligns with the realities of NZ businesses. Moreover, in addressing the gap we elucidate the rhetorical methods whereby a narrative encouraged businesses to presume that engaging with Asia and specifically China would be easy.

NZ is a small, open economy of mostly SMEs, with a history of neoliberalism and several FTAs in the Asia-Pacific (MFAT 2008a, 2019a). Using constructivism, we analyse how NZ policy-makers' discourse aligned, or misaligned, with the perceptions of NZ businesses and especially their actual capabilities and resources. Our extensive document analysis starting from just before NZCFTA shows the NZ government's narrative emphasised almost unequivocally that FTAs (notably NZCFTA) would boost firm competitiveness and open up growth opportunities. The government's purpose was 
to secure wide trade enactment of NZCFTA. Our interview analysis of NZ firms, which included 31 SMEs (following the European definition: fewer than 250 employees), and five larger firms, further shows the government narrative matched business-owners' opportunity perceptions. Although we found strong suggestions that the official narrative reinforced those perceptions, our sample did not allow firm causal conclusions. However, we demonstrate that pursuing these opportunities did not serve most businesses' interests. The narrative elided the fundamental obstacles of specific practical challenges awaiting most businesses, given their psychic distance from Asian markets and relatively small size. Simply put, most businesses lacked requisite scale, resources and capabilities as well as relevant channels to realise the perceived opportunities. The narrative promoted thus aligned with business perceptions but misaligned with achievable reality.

The study contributes to constructivist institutionalism by examining how overly rosy discourse promoted enactment and in fact over-enactment entering the Chinese market, after the more-often-studied stage of mobilising support for the formal liberalisation (NZCFTA itself). It did so by fostering the uncritical presumption that enacting the FTA would benefit most NZ businesses. Overpromising and uncritical supporting narratives may sow the seeds of future disappointment when businesses that uncritically accept them face a mismatch with realities like those here of inadequate scale. We also contribute by dissecting the mechanisms of presumptions. We describe 'presumptive tilt' - a slant towards some presumption about reality rendering it difficult to refute. Here we find this tilt mostly propped up by 'peripheral evidence' the government shifted to centre stage. Peripheral evidence is a concept we define as uncontested and widely observable, but not centrally relevant, information that can be made central to the narrative for a targeted audience, thus displacing more relevant 
concerns. Its centring crowded out critical discourse on the fundamental obstacles awaiting NZ businesses in reality.

Next we summarise existing literature on enabling institutional change and discourse, before outlining recent NZ FTAs in the Asia-Pacific, including NZCFTA. After the Methodology come the Findings, organised into four rationales whereby government shaped the narrative supporting enactment of the enabling NZCFTA, and how that narrative aligned with businesses' opportunity perception but misaligned with their reality and thus interests. The Discussion details our contributions to constructivist institutionalism and policy implications. The Conclusion recaps arguments and addresses limitations.

\section{Literature Review}

Enabling institutional change, evolving dominant narratives, and presumptions

Firm strategy is both constrained and enabled by formal and informal institutions. Formal institutions, like trade agreements, are most visibly made and changed by powerful actors, including government agencies and professional organisations, and construct a framework for economic and social interaction (Pierson 2000, Streeck and Thelen 2005). Of particular global importance since the 1970s, neoliberalism has permeated market coordination and driven trade agreements.

Neoliberalism posits that institutional frameworks should enable free-market coordination (Harvey 2007). Neoliberal policies have encouraged free trade by liberalising and deregulating markets and reducing trade barriers and tariffs. However, such enabling institutional changes require enactment by businesses to become effective (Hall and Thelen 2009). This requires businesses to accept certain new norms informal institutions - such as the desirability of trading with a new market. Research 
has emphasised how narratives legitimise institutional change and mobilise actors (Jennings and Greenwood 2003). Narratives can communicate the need for institutional change or disseminate new 'rules of the game'. They alter institutions' underpinning 'logics' and supply practical frameworks for action (Rao et al. 2003). Narratives shape perceptions about envisaged change, including likely winners and losers (Fligstein 2001). Enabling institutional change requires a convincing narrative that provides scripts for enactment and anchors for sensemaking.

Narratives evolve through discourse. They are negotiated as actors construct and communicate stories to shape what audiences believe or want. Consequently, scholars have increasingly studied rhetoric's role in shaping dominant narratives to mobilise actors (Duina and Bok 2014). Actors use rhetorical manoeuvres to persuade audiences that altering institutional logics is in their self-interest, generally desirable (Werner and Cornelissen 2014) or inevitable (Watson and Hay 2003). Rhetoric can manipulate groups and influence perceptions (Walter 2017). For instance, Brown et al. (2012) show how rhetoric distilled a dominant narrative from competing logics by strategically employing moral norms and evoking emotions. Institution-makers, as architects of trade policy, also clothe institutional change in rhetoric to create a dominant narrative justifying change and encouraging enactment (Green and Li 2011). Constructivists have argued that particularly during crises, powerful actors can foster new ideas to influence businesses' perceptions and thus strategy and behaviour (Blyth 2002); but institutional change is not limited to crises (Hay 2006).

Homing in on a major rhetorical strategy, recently scholars have argued that actors create presumptions, or simple decision-making rules, to make an argument 'efficient' (Hoefer and Green 2016). That is because actors have limited cognitive abilities, just as historical institutionalism assumes bounded rationality (Hay 2006). 
Arguments induce presumptions to convey or reinforce one viewpoint by offering frameworks for sensemaking that conduce to it efficiently - namely, with low effort, because accepting it lightens decision makers' cognitive load and takes less evidence than questioning it (Hoefer and Green 2016). Godden and Walton define a presumption as 'a modal status (or property) of a claim (or proposition) indicating that the burden of proof with respect to that claim rests with anyone who would reject it' (2007: 314).

Presumptions render language performative in shaping actors' communication and judgement, thus influencing business practices, values and conceptions (Hoefer and Green 2016). The decision-making scripts presumptively slipped in are again more easily followed than challenged (Brown et al. 2012). This leads to presumptive tilt; a situation where presumptions reduce opportunities for critical discourse and 'tilt' the narrative towards a conclusion favoured by one party. While initially attractive, such accepted scripts might be scrutinised, and their acceptance even rued, later (Hoefer and Green 2016).

Such decision-making scripts may thus become enacted, internalised in practices and institutionalised. Hence understanding presumptions as a rhetorical strategy to get enabling change enacted illuminates cognition and legitimacy judgments. How governments as key change agents use presumptions to promote trade liberalisation competitiveness remains poorly understood.

\section{The role of discourse in trade liberalisation}

To foster competitiveness and innovation, many advanced capitalist economies in the last decades have unleashed freer trade through neoliberal market reforms. Several studies consider how discourse legitimised and influenced trade liberalisation (Morin and Carta 2014). Take Siles-Brügge's (2011) novel analytical strategy demonstrating how the European Commission's Directorate-General for Trade marshalled ideas and 
language to construct an imperative for the 2009 EU-Korean Free Trade Agreement. Similarly, analysing the World Trade Organization's (WTO) 2005 Hong Kong meeting, Wilkinson (2009) shows that 'crisis discourse' helped drive trade liberalisation. Framed through a core story, metaphors and images, it implied that interrupting liberalisation would harm members. And the European Commission used the rhetoric of 'managed globalisation' to reframe its Member States' interests into a consistent trade policy (Meunier 2007).

A parallel discourse depicts small states as particularly vulnerable to global competition. Lee and Nicki (2010) illustrated how international policy leaders turned around the discourse of vulnerability to urge small states to embrace globalisation by adopting neo-liberal policies including trade liberalisation. Less understood is how the liberalisation and its discourses (mis)match true and perceived opportunities at firm level, particularly in small, open economies like NZ.

We could expect rhetorical strategies in narratives that encourage enactment of trade opportunities to be controversial in trade liberalisation because evidence is divided about the latter's effect on businesses (Kneller et al. 2008), particularly SMEs (OECD 1997). For example, whilst Tambunnan (2008) found trade liberalisation afforded Indonesian SMEs growth opportunities, the same year Obokoh (2008) found most of 500 Nigerian manufacturing SMEs lost profits post-liberalisation (although lower profitability and higher growth can co-exist).

Some scholars warn that trade liberalisation alone does not incentivise firms to innovate to acquire new knowledge, and that institution-makers should address both market and non-market institutions to raise economies' competitiveness (Cimoli et al. 2006). Peres and Stumpo (2000) found that trade liberalisation in 10 countries affected SME performance differently; that performance mainly depended on macroeconomic 
conditions, including GDP growth and inflation; but that sectors varied substantially. Pula (2018 shows that other macroinstitutional factors like quality of governance influence firm performance more than embracing free trade.

When no side can claim irrefutable victory on the evidence, institution-makers' rhetoric and narratives may well substantially frame how businesses perceive and potentially enact trade liberalisation (Cornelissen and Clarke 2010). Interpersonal communication and individual cognition intertwine here, as discourse both influences cognition and reveals it (Cornelissen et al. 2015). What happens, though, when successive neoliberal-leaning governments construct a dominant pro-trade liberalisation narrative which also matches the perceptions of opportunities by embedded business agents? And, most interestingly to us, how might that narrative (mis)align with the latters' real interests?

\section{NZ's trade liberalisation and promotion programmes in Asia: Bolstering enactment}

NZ was an early adopter and active promoter of neoliberal trade reforms in the AsiaPacific. Even before the Fourth Labour Government (1984-90) ushered in 40 years of bipartisan neoliberalism, the country entered a trade agreement with Australia (CER: Closer Economic Relations) in 1983, albeit more to stimulate competition domestically than open up overseas markets (OECD 1989: 5). From the late 1990s, however, FTAs shifted away from traditional, psychically close markets, towards Asia. From a NZ firm perspective, Asian markets have high 'psychic distance': impediments to information flow between firms and markets, including language, cultural norms, regulations and business practices (Liesch and Kight1999, Evans and Mavondo 2002).

Following an agreement with Singapore in 2000, NZ's FTAs surged in number 
and scale. They included the Trans-Pacific Strategic Economic Partnership (2005, forerunner of the Trans-Pacific Partnership), NZCFTA (2008), and ASEAN-AustraliaNZ (AANZFTA) (2010), the Comprehensive and Progressive Agreement for TransPacific Partnership (CPTPP) (2018) plus agreements with several individual ASEAN member states (MFAT 2019a). NZCFTA has now eliminated tariffs on over 97 percent of NZ's goods exports to China, except for a few products and dairy, where tariffs will be eliminated by 2024. By 2018, all tariffs for imports from China had been eliminated (MFAT 2019b). NZCFTA explicitly intended to foster the competitiveness of NZ businesses, including SMEs. Article 176(1) aims ‘(b) to promote a favourable trading environment for the development of SMEs; and (c) to build the capacity of SMEs to trade effectively under this Agreement'. SMEs, officially defined in the NZ context as having fewer than 20 employees, make up over 97 per cent of NZ enterprises (MBIE 2013); the percentage is even higher under the European definition of SMEs (under 250 employees).

China surpassed the US and Japan to become NZ's second-biggest trading partner after Australia in late 2008, then the biggest in early 2013. Exports to China grew by about 170 per cent from 2008 to 2012. Primary products, especially processed/unprocessed food, drove this trend (+188 per cent), while manufactured exports rose 36 per cent and elaborated manufactured products, 26 per cent (Statistics NZ 2013). However, that China's total imports increased by about 70 per cent from 2008 to 2012 (World Bank 2016) suggests that rises in NZ exports related at least partly to growth of the Chinese economy. Simultaneously, moreover, US manufacturing exports to China grew about 45 per cent (US Census Bureau 2016) and those of the EU27 by 81 per cent (Eurostat 2016), both without an FTA. If anything, then, NZ manufacturing lost ground relatively over this period. Thus government faced a 
problem: having expended so much in energy and resources on trade liberalisation and the FTA, how should it respond to the 'wait-and-see approach' of many SMEs, and the reported difficulties of others already engaged. In particular, languishing value-added exports suggested many businesses, especially SMEs, had yet to develop the capabilities and strategies to engage in China and Asia with real success.

The government's response was a co-evolving strategy to promote enactment and vindicate its investments. From 2010, the government switched how it supported internationalisation. NZ Trade and Enterprise (NZTE), a government business development agency, began focusing more on 500 selected businesses with 'Focus 500' in 2011 (New Zealand Government 2013), becoming 700 in 2014. This scheme channelled funding and staff availability to companies that had 'scale, commitment and drive to succeed internationally' (NZTE 2013). To intensify their internationalisation, these firms received financial and other incentives, including access to market research, and free or subsidised training and advice on market expansion, brand and strategy development (expert F).

NZTE also promoted business engagement with Asia actively. In 2010-11, NZTE had a budget of NZ\$180 million and 520 employees (NZTE 2011). About onequarter of its 225 off-shore employees were now deployed in China. In 2012, the 'NZ Inc. China Strategy' was released, mapping out a vision to 2015, for a 'whole-ofgovernment approach to growing exports and new markets' (NZTE and MFAT 2012: 15). Hence, the government started actively endorsing exports to Asia, particularly China after NZCFTA.

\section{Methodology}

We use data mostly post-NZCFTA to investigate how the NZ government's discourse 
of trade liberalisation towards emerging Asia and particularly China evolved. We analyse the dominant narrative and how it related to the perceptions and realities of NZ businesses, mainly using interviews and document analysis.

First, as a window into how the government shaped public discourse, we collected 129 publicly available documents and audio files from sources featuring officials and government institutions published between July 2007 and May 2016. Of these, 68 ultimately informed our inquiry to understand the narrative created around NZCFTA and business opportunities due to trade liberalisation with China and emerging Asia.

We excluded documents that only used statistics or facts, not persuasive language; topics extraneous to NZ export business such as Chinese tourists and/or migrants; and re-publications through multiple media channels. We included documents bearing on FTAs in emerging Asia, especially NZCFTA, economic engagement in the Asia-Pacific, and general business relations between NZ and emerging Asian markets. Within this scope fell reports, press releases and videos from websites of various government-related institutions, such as government-funded not-for-profit trusts, city councils, government ministries and government agencies, including NZTE. Document analysis especially scrutinised the NZCFTA's rationale, its purported benefits and risks to firms. Additionally, we conducted 12 face-to-face interviews with key personnel inside and outside state bodies, who offered informed perspectives about trade liberalisation and Asian business engagement, including trade negotiators, directors of Crown Research Institutes and industry experts.

Second, we interviewed owners and/or managers of $36 \mathrm{NZ}$ businesses which either had entered China or were considering doing so soon, to see how the government 
narrative on China matched business perception and realities. We also gathered secondary data about these firms, such as company documents and press releases. Eight businesses had fewer than 20 employees, 23 from 20 to 250 employees and five had over 250 employees and/or were subsidiaries of an overseas-based multinational. Thus, by the European definition of SMEs, 31 businesses were SMEs, and five larger firms. We profiled companies from secondary data such as newspaper articles and company webpages. Table 1 profiles basic firm and firm-participant characteristics. Insert Table 1 Company and participant profiles about here

For each business, we conducted one in-depth, semi-structured interview with the owner or a senior manager, who discussed their Asia strategies and government policy. Interviews lasted about 60 minutes. Two researchers took part in each interview to ensure it covered the main guideline topics. Participants were asked to reflect on the reasons for their Asia engagement, and on their strategic choices, opportunities and challenges. We also asked which parties influenced and supported their internationalisation towards Asia, and especially China, such as banks, consultants and NZ government representatives. Although not inquiring exactly how the FTA had shaped their thinking/strategy, we did ask how interviewees perceived the FTA and how the government supported their strategy. Finally, we asked in which markets they perceived future growth opportunities.

\section{Findings}

\section{Government rationales for engaging with China: Shaping the dominant narrative}

Our data analysis reveals the NZ government's rhetorical strategy to encourage businesses to re-focus towards emerging Asia, especially China. Awareness was raised through various channels, formal and informal, including re-oriented agencies, press 
releases, conference support and business workshops. Importantly, the government released a 'NZ Inc. China Strategy' initiative stressing future opportunities in China based on predicted Chinese income growth and the market's size (NZTE 2012), a dual rationale recited by many owners and managers. We discerned four rationales in rhetoric invoked to talk up business opportunities in China and other emerging Asian markets: (1) the growth and (2) the large size of the Chinese market; (3) being first (NZ was the first Western nation to conclude an FTA with China); and (4) China is our future. NZCFTA was often a focus of the narrative as a starting point, and it was key to the four rationales. Although these are neither exclusive nor exhaustive (and the first combines two different kinds of growth), the resulting framework serves to compare the government narrative with business perceptions and achievable realities. We now present findings on the four rationales in that order.

The growth rationale. The government reiterated the recent and forecasted growth of China and/or growth opportunities there for NZ businesses. Four of NZ Inc. China Strategy's five objectives focus on growth, and that word appears 35 times in the document. Keywords such as 'double', 'quadruple', 'sustained period of wealth creation', 'significant development', and 'predictions' populated official documents and speeches regarding growth. The government also referenced industry and consultancy reports, such as Boston Consulting Group, Wine Intelligence and the OECD, and reports from their government agencies, such as NZTE or Ministry of Foreign Affairs and Trade (MFAT), to support their narrative (NZTE and MFAT 2012).

References to expected growth in China and elsewhere in emerging Asia by NZ officials were largely positive, confident and uncritical. Typical phraseology included: 'The FTA will help facilitate further growth in these and other services exports' (MFAT 2008b: 10); 'the potential is huge' (Key 2009, Prime Minister); and 'Our exports of 
wine are still small - $\$ 23$ million last year - but the annual growth rate is well above 50 per cent' (Groser 2012, Minister of Trade). However, sometimes a more moderate tone cautioned about challenges: 'China has huge growth potential but NZ companies need to target specific sectors and find the right partner' (Mark Templeton, former CEO, Actronic Technologies in NZTE 2012: 4).

The size rationale. Related to growth of the market and business growth, officials frequently invoked the sheer size of China's market as a golden opportunity. For example, a double page of the NZ Inc. China Strategy ran a single quote from the China National Bureau of Statistics, writ suitably large (NZTE and MFAT 2012): 'Over half of China's ... 1.35 billion ... population now live in urban areas'. Keywords and phrases about size often took (tiny) NZ as a reference point, like: '36 times the size of NZ, population over 300 times the size of ours'. Other wordings included 'the size astounds', 'sheer size' and 'vast size' (NZTE and MFAT 2012). Typifying the narrative was a press release on a government website discussing NZCFTA: 'The global market represents billions of people and billions of potential export dollars that NZ businesses can capture' (Goff 2008, Minister of Trade).

A big country can mean, as it were, big competition. NZTE did warn: 'You should also not underestimate the size and quality of your competition in China' but immediately added, encouragingly: 'The [NZ] government's pro-growth policies have produced a host of businesses pursuing each and every opportunity' (NZTE 2012: 3).

The rationale of being first. NZ was the first Western nation a) 'to conclude a bilateral agreement with China on its accession to the World Trade Organisation'; b) to 'recognise China's status as a market economy' (in May 2004); and c) to 'enter into FTA negotiations with China'. It was also d) the first in the OECD 'to sign a high- 
quality, comprehensive and balanced FTA with China', in April 2008 (NZTE and MFAT 2012: 7).

Government representatives argued these 'four firsts' yielded distinctive or even unique competitive advantages for NZ businesses, for instance: 'with it [entering the FTA] came a unique competitive advantage' (MFAT 2017). Other phrases included 'being first counts'. NZ's 'first mover advantage' was often said to produce unparalleled opportunities. Thus the Minister of Trade: 'I see a fantastic opportunity ahead of our country as it seeks to add its trade, technology, people to people, investment and other links with China. No country has a better platform than NZ to take advantage of China's extraordinary growth' (Groser 2012). While some officials acknowledged first mover advantage was temporary, they painted ongoing benefits: 'Some of this benefit may be eroded over time as other countries sign agreements with China, although NZ will benefit from already having relationships and supply chains set up' (Bowman and Conway 2013).

The rationale of China being our future. Historically NZ's trading partners have been culturally or psychically close, like the UK and Australia. For many NZ businesses, trade with China was still only a distant possibility, but government narratives implicitly urged them to get in early. Above all, China was 'going to be the most important economy in the world, and the only argument is whether it is in 10,15 or 20 years' (Groser 2012, Minister of Trade).

This rationale rang with upbeat phrases like 'this new reality', 'future prospects', 'ambitious future goal', and 'confident in the future'. The relationship to NZ was portrayed as accepted and approved with such statements as: 'China is a huge and growing part of our future (Groser 2013, Minister of Trade) or 'Avoid the negativity: China is the future. We've got to look East' (NZTE and MFAT 2012: 26). Often 
backing up this optimism was the claim that the FTA would bear fruit soon. For example, after the Global Financial Crisis: 'While the immediate future may look grim, we can be reassured that our close ties with the countries of Asia will pay dividends when the global economy starts to pick up.' (Asia NZ Foundation 2009: 3).

The narrative was supported by official recitations that new generations of New Zealanders should future-proof themselves by learning Mandarin. For instance, thenPrime Minister Key urged NZ schools to offer Mandarin (NZ Herald 2013), and appealed to parents and children: 'I think it makes a lot of sense for our youngsters to be able to understand the language so they can understand this market' (Lush 2010).

\section{Perceptions and fit of the businesses to the four rationales}

Interview analysis reveals that the perceptions of the 36 managers/owners of $\mathrm{NZ}$ businesses largely matched the government's opportunity narrative. While some suggested NZCFTA factored into how they perceived opportunities in China, we cannot claim it alone influenced their decisions. Nonetheless, businesses were well aware of NZCFTA, and believed it offered them opportunities. For many growth-oriented businesses, Asia, specifically China, became a priority region after 2008.

The narrative around the growth rationale fitted perceptions of managers in Asian markets. They used words such as 'exciting opportunity' and opined it should be easy to 'quadruple' sales - a conspicuously specific magnitude and likely a direct echo of the government narrative unless inspired by a common source. However, many businesses which had just started engaging with Asian markets, or not yet forged relationships there, defined the growth potential abstractly, or vaguely, and many either did not single out Asian markets, failing to identify their variety, or conflated Asia with China: 'We see the Asian region as a huge growth potential ... but we haven't identified how we can leverage our skills right now... We're at the discovery phase of having 
someone on the ground in Asia to actually find those opportunities' (\#1). As to what was achievable, small firms often lack the capacity to match fast-growing demand or to compete on price. For instance, one smaller food firm, in fact, had withdrawn from China, as demand from its single buyer exceeded its annual capacity; boosting capacity would have taken significant investment and posed unacceptable risks.

Secondly, managers likewise strongly believed the size of China's market and sheer population would yield concrete opportunities-somehow: 'I think just the scale of the market - the opportunities will be there. China is going to be important - just the size of it' (\#20). 'It's the size of the market ... At the moment the largest market for airport development is the US, but by 2020 it is predicted that one in every two people will board an aircraft in Asia so it will be the largest market ... There will be a lot of work in Asia ... But we've got nothing new happening in China at the moment ...' (\#28).

Although sometimes echoing common knowledge, some managers made the same size comparisons as government, so the theme certainly resonated: '[In] China ... you've got probably 100 million who are well off and that's still 25 times the size of the NZ market' (\#33). 'For success we want to put a few million [of product] into China. Then we'd only be scratching the surface. If we get 2 million [of product] in the NZ market with a population of 4 million people, imagine what potential there is up there' (\#29).

However, achievable reality was once again a different matter. Most businesses in our sample were SMEs operating in small niches, which reflects NZ's business population. For most of the 97.2 per cent of NZ businesses with under 20 employees (MBIE 2013), the vastness of the Chinese market should have been irrelevant or even off-putting, as they possessed neither the scale nor capabilities to take advantage of it 
and might in fact drown under demand like the food firm that had to withdraw. Another owner pointed out his SME's lack of financial resources made it hard to build new relationships without additional support. Others never achieved their growth aspirations: 'We spent quite a bit of money on the launch, it was just over the top ... But [our Chinese business partner] only bought about $1 \%$, of what they indicated and they just stopped buying ... I suspect they are still using the packaging and branding; but obviously they are not using our product in it anymore' (\#25).

Even larger SMEs lacked necessary resources, capabilities and channels to connect with Chinese business partners and consumers. For example, one of the larger food firms commented that competing on price is often difficult in Asia due to the lack of scale. Another CEO reflected on opportunities for NZ firms based on his experience: 'The issue with NZ businesses is they do not have the capability to do business in China. It's not a place for beginners. It's pretty brutal' (\#8). Also, for him, and others, scale put pressure on price and on partnerships because 'without scale you're not important to your Asian partners' (\#8).

Moreover, their existing products did not fit the demands of Chinese consumers. One interviewee explained: ' [Chinese consumers] don't really want us because we're seen as Western. We're seen as expensive' (\#11). Industry experts pointed out that China's price-sensitive mass market was a poor fit for many NZ product offerings, while few businesses had the cultural knowledge and channels to reach customers buying premium products. This gave some managers pause: 'The issues are the huge differences in culture ... Asia is probably a step too far at the moment where the business is; too risky' (\#12). Most could only hope to sell to expats and Western businesses. Moreover, even the large firms sampled reported they could not achieve the scale to make a profit. As one manager put it: 'In Asia, we are a lot closer to the wire; 
the wire being of course losing money. We have about eight staff in China and that's probably not enough ... it probably needs to be in the hundreds to make it work' (\#19).

Next, the narrative around being first also matched some managers' perceptions. Despite their limited understanding about any existing competitors, NZ's being the first Western nation to conclude a FTA with China boosted confidence. Managers said the government had been 'doing great work around the free trade agreements' (\#2), or that it was 'incredible', 'amazing' or 'a great opportunity', influencing their decision to seek opportunities in the region: 'The FTA in particular seems to be welcomed by businesses' owners, who increasingly believe that China should become, or is now, a "focus market"” (\#31). "What is changing in Asia is that NZ does have free trade agreements in place with China ... That is changing the face of our business' (\#32). Such perspectives imparted urgency.

Some managers predicted a unique advantage over their competitors, and foresaw the strong relationship at government level affording opportunities for businesses. For instance, an owner reported: 'It's very positive that NZ-China relations are so strong ... China is using NZ as an example as a Western country ... Briefs produced by the Beijing government say that NZ is of interest, and to be treated in a certain way; those brief sheets are very beneficial ... Initially, we had the intention of saying we can't do it (sell in China) but now we know in five years, China will be our biggest customer. But we don’t quite know how to do that yet' (\#21). Others thought they would enjoy first-mover advantages in China. For example, a vineyard manager saw a window of opportunity to shape customer preferences in Asia, which lacks a deep wine culture: 'The opportunities are to establish a NZ wine brand at the forefront of new wine consumers' minds, so for Asia as a market-place, wine is a new thing, it's a Western thing.' (\#4). Other business owners, however, were mindful that NZ enjoyed 
no unique advantage, as customers equally valued European brands already competing there.

Finally, many managers located future opportunities predominantly in China and Asia more widely with the same inevitability as government narratives imparted, despite not currently understanding those markets: 'So there is an opportunity in China; it's how to connect with that opportunity that we are still debating' (\#34); 'Singapore, Malaysia, Indonesia ... we believe there is great opportunity for us ... But we are going to have to fight with the current market conditions. I don't know what those are' (\#36); 'I think it's a big opportunity in short. As we go, we will become more and more convinced and therefore be able to commit more and more to the size of the opportunity' (\#4).

That speaking Mandarin might be critical to success in China also came up several times. Some managers stressed their businesses must acquire language capabilities, while others agreed with Prime Minister Key that NZ children should learn Mandarin. For example: 'Anyone going up there as an expert has to learn Mandarin, otherwise it's just too difficult.' (\#30); 'It's interesting hearing John Key talk about our children learning Mandarin because our key people working up in China are learning Mandarin.' (\#35); 'As I keep on telling young people here at the universities or schools they should be learning Mandarin' (\#24). Overall, owners and managers often raised language as a major obstacle. Those who thought their own staff could learn Mandarin competently from scratch betrayed extreme optimism. Hiring bilingual immigrants would have been more useful, but difficult in SMEs given their size.

Overall, the government narrative matched the perceptions of the managers, who utilised those perceptions in their strategies, even though most had minimal experience in the Chinese or wider Asian market. Significantly, however, few had really reflected 
on whether they would need to adjust their business model or acquire specific skills (except language). Managers were typically optimistic about the opportunities, as an industry expert confirmed: 'I always found it very strange that people who were very smart in business, when they crossed the border, it was as if due diligence went out the window with China' (expert B). Seemingly uncritically, managers thought opportunities in China was ripe for the picking - ready to be exploited. Little surprise, then, when actual business success disappointed went unmet. Businesses achieving initial growth still struggled to find a profitable business model, or to sustain growth over time. One manager explained that his business partner stopped buying his product, which had grown considerably growth in a short period, suddenly and without explanation. An industry expert concluded: 'The NZ-China landscape is littered with failures of NZ companies that have tried different things and hasn't worked' (expert J).

To repeat, alignment with the four rationales falls short of establishing that the government narrative either created the firms' perceptions or caused businesses to go to Asia. Causal claims are especially hard in a constructivist framework because businesses are also influenced by other media and perceptions often draw from common sources. The China narratives were not peculiar to the NZ government, and some terminology and references to the countries' sizes were perhaps inevitable.

Nevertheless, interview analysis strongly suggests the government's almost entirely uncritical narrative contributed to the attempted re-orientation towards China and Asia generally by strengthening confidence in perceived opportunities (thus anchoring sensemaking) and increasing engagement. Certainly the NZ businesses perceived NZCFTA itself positively. Firms could not possibly have been unaware of the government narrative, which dominated the media. Administrations of both main 
political colours had promoted NZCFTA (signed at the end of Labour's tenure) and Asia generally, so the line was consistent across the political spectrum and time.

Ultimately, competitiveness and innovation were not enhanced for most firms because, even though many attempted to enact the possibilities enabled by NZCFTA, the opportunities mismatched their capabilities and hence their real interests. Few appreciated that significant innovation would be necessary to begin to generate success. Thus enactment and over-enactment in entering the Chinese market did not deliver on NZCFTA Article 176(1)'s aims to promote a favourable trading environment for SMEs and build their trading capacity.

\section{Discussion}

The role of narratives and discourse in institutional evolution has attracted recent attention (Cornelissen et al. 2015). Mostly this work highlights the part played by narratives in changing institutional logics and mobilising actors to support or accept this change (Green and Li 2011). By contrast, our study investigates empirically the role narratives play in encouraging the enactment of enabling institutional change in independent business actors' strategies.

The empirical findings thus contribute to constructivist institutionalist literature in three ways: (1) showing the sheer extent to which a pro-enactment narrative crowded out critique, misaligned with the achievable reality of the businesses and so potentially contributed to over-enactment, unrealistic goals and failed ventures; (2) spotlighting trade liberalisation discourse aimed at business enactment of opportunities already enabled by formal institutional change, which amounts to a call for action rather than a change of institutional logic; and (3) identifying mechanisms for presumptive tilt in the 
government's pro-enactment narrative, especially the role of peripheral evidence. This leads to policy implications.

Existing studies have considered how discourse legitimises institutional change (Blyth 2002). These studies help us understand how political actors win legitimising support in advance for formal trade liberalisation (Siles-Brügge 2011), but we know less about how affected firm actors are mobilised once the negotiators go home and the ink has dried on their agreements. Thus, to date, research has concentrated on how narratives change institutions' underpinning logics, rather than the way narratives shape whether, and how, independent business actors incorporate into their strategies the possibilities enabled by change (Werner and Cornelissen 2014). Yet enabling change, even where already legitimated and realised in such formal institutional rule rewriting as FTAs, may languish unenacted, a dead letter on the page. An encouraging enactment narrative can help to overcome inertia and mobilise actors - even if the change runs against actors' self-interest for lack of relevant capabilities and resources. Building on Hoefer and Green (2016), our study empirically shows political actors tilted the perceptions of their audience towards presumptions that favoured enactment. Presumptive tilt not only channels and confirms actors' perceptions of opportunities, and simplifies sensemaking by lightening cognitive load, but also ignites and fans an urgency for business to enact these purported opportunities. Thus the narrative serves not to change institutional logics, but as a call for action.

While we now know more cognitive mechanisms by which presumptions can shape discourse, just how presumptions are induced and ultimately aim to influence action deserves further attention (Hoefer and Green 2016). Our findings identify the use of peripheral evidence, for propping up a presumptive tilt. Based on our findings, we define peripheral evidence as uncontested and widely observable information that can 
be made central and salient to the narrative thread for a targeted audience despite lacking relevance and therefore belonging on the periphery. Peripheral evidence includes general facts and authoritative and widely accepted opinion and predictions, often extrapolated from facts. Rhetorically promoting peripheral evidence to centrestage lends it a specious relevance. Moreover, centring peripheral evidence generally aims to displace fundamental arguments which belong in the centre that could weaken the maker's case and encourage critical discourse. Political actors centre peripheral evidence by tenuously connecting information to a narrative that favours their conclusion or reflects their perception. The information may be not only irrelevant but misleading and, if acted on, damaging for the target audience.

In our study, centring peripheral evidence about the size and growth of the China market, NZCFTA being the first Western FTA with China, and China's importance to NZ's future nourished the perception that businesses would automatically grow in China, and imparted urgency. Businesses lacking a positive China strategy came across as lacking future or growth orientation. Thus, centralising peripheral evidence was one way to prop up presumptive tilt towards enactment, try to manipulate how individual businesses perceived their opportunities (Walter 2017) and crowd out or discourage critical discourse during institutional change. One notable comment that was almost directly anti-critical was 'Avoid the negativity: China is the future. We've got to look East' (NZTE and MFAT 2012: 26). We might expect that businesses will eventually adjust their strategies if/when the results disappoint (Hay and Wincott 1998), but quite possibly only after losses and failures.

Further elucidating presumptive tilt based on our findings, we argue that through skilful deployment of peripheral evidence presumptive tilt can promote a 'rationalised myth' (Meyer and Rowan 1977) in complex change; and the more complex the change, 
the more alluring the presumptive 'simple decision-making rules', as they can lighten decision-makers' cognitive load (Hoefer and Green, 2016). Here the presumptive tilt encouraged firms to target China, even when China might well be unsuitable for them. Businesses, particularly SMEs, usually internationalise with notable caution and tend to grow gradually into more familiar markets instead, by developing strong networks with customers that facilitate market learning (Johanson and Vahlne 2009). This was quite unlike how several businesses we studied were approaching China, suggesting that critical discourse was stifled due to an overemphasis on peripheral evidence. The final contribution of this study is to show how a dominant government narrative to legitimate an FTA encouraged enactment, crowded out both caution and critique and obscured fundamental challenges to business in realising its purported opportunities. What should have been central was most target businesses' strategic inability to realise the opportunities, potential obstacles and what would be needed to overcome them.

Ultimately, whilst the perception of our managers was already aligned with the government's narrative, the findings suggest that narrative further inclined them to enact perceived opportunities without critically considering their small size and limited scale vis-à-vis a large, fast-growing market. Thus, this empirical study further contests neoliberal claims that trade liberalisation is sufficient to enhance competitiveness, innovation and growth. Certainly, although we could not establish causation, overenactment at least followed the government's narrative. The fact that failed ventures were predictable and indeed likely in a country where over $97 \%$ of firms have fewer than 20 employees, raises the question of how far legitimating or pro-enactment government narratives should encourage caution and critique. This question deserves full exploration elsewhere, but we offer some initial thoughts. 
Shane (2009) has advised policymakers not to encourage firms or individuals with limited chances of success when shaping institutional settings. We think governments should be careful of exposing firms to such risks both morally - that is, for firms' sake - and prudentially - that is, for government's own sake, assuming government acts on behalf of the national interest and also wants to keep credibility or, for elected representatives, win re-election. To overcome inertia, policymakers may well need a narrative rationale for enactment. But they must appreciate its potential consequences for businesses when this affects how those businesses perceive opportunities. In particular they must heed that a presumptive tilt and centring of peripheral evidence may indeed stifle a critical discourse which could avert failure. Hence, policymakers should also foster critical discourse around the narrative to accelerate learning and individualisation of the opportunities arising from the enabling institutional change.

Finally, enactment of enabling institutional change requires businesses to positively embrace new norms under uncertainty, so policymakers necessarily craft strong supporting narratives. The NZCFTA narrative had to activate a desire to trade with a new, unfamiliar and thus very uncertain market by boldly accentuating positives: major growth opportunities. Because it was unbridled by any critical official discourse about central realities, the necessary encouragement created unrealistic expectations. Thus very strong narratives to overcome high uncertainty about enabling institutional change may sow the seeds for disappointment as policymakers need to overpromise to encourage enactment in trade liberalisation, and one might speculate, in other domains. 


\section{Conclusion}

Using a constructivist framework and grounded approach, we investigated how the NZ government's positive narrative encouraged businesses to enact NZCFTA and pursue wider opportunities in emerging Asia. We show how political actors created presumptive tilt, specifically by centring peripheral evidence. The narrative at least matched and must have confirmed perceptions of businesses. It impelled urgent enactment even where not in businesses' interests. Many SMEs lacked requisite capabilities, resources, size and scale to engage with the market. Grasping the need for these might have pushed the more promising facts back to the periphery. By centring peripheral facts, the narrative sought to manipulate opportunity perceptions and sensemaking of individual businesses and crowd out or discourage critical discourse when businesses first enacted institutional change.

The study has limitations. We only included NZ businesses which either had entered China, or were considering entering it soon. The businesses therefore do not represent NZ's overall business population. While such a sampling approach is common in qualitative research, future research could analyse the perceptions of businesses that 'stayed at home'. These, too, are probably affected by trade liberalisation through heightened local competition, and researchers could analyse how they perceived trade liberalisation to impact their growth opportunities. In addition, Asia's (re-)emergence is a defining twenty-first century megatrend, and we cannot make causal claims that the NZ government narrative alone has shaped businesses' strategic orientation towards Asia, especially in a constructivist framework. Nonetheless, the findings suggest that the government narrative contributed to a re-orientation towards Asia by strengthening business confidence in pursuing this opportunity. Finally, NZ's nature as a small open economy, with many very small businesses could limit the transferability of our 
findings to larger economies. It may well be that smaller firms follow their government's narratives more closely than do larger counterparts with global reach. A future study could valuably inquire whether and if so, how, trade liberalisation narratives influence large MNCs.

\section{Disclosure statement}

No potential conflict of interest was reported by the authors.

\section{References}

Asia NZ Foundation. (2009), Annual Report 2008/2009.

Baldwin, R.E. and Forslid, R. (2000), 'Trade Liberalisation and Endogenous Growth: A q-theory Approach', Journal of International Economics, 50 (2), pp. 497-517.

Blyth, M (2002), Great transformations: Economic ideas and institutional change in the twentieth century. Cambridge University Press.

Bollen, Y., De Ville, F., and Orbie, J. (2016), 'EU Trade Policy: Persistent Liberalisation, Contentious Protectionism', Journal of European Integration, 38 (3), pp. 279-94.

Boräng, F., and Naurin, D. (2015) "“Try to see it my way!” Frame congruence between lobbyists and European Commission officials', Journal of European Public Policy, 22 (4), 499-515.

Bowman, S. and Conway, P. (2013), The Outlook for China's Growth and Its Impact on New Zealand Exports, Treasury Working Paper No 13/16.

Brown, A.D., Ainsworth, S., and Grant, D. (2012), 'The Rhetoric of Institutional Change', Organization Studies, 33 (3), pp. 297-321.

Cimoli, M. (2006), Institutions and Policies Shaping Industrial Development: An Introductory Note, Laboratory of Economics and Management Working Paper No. $2006 / 02$.

Cornelissen, J.P., Durand, R., Fiss, P.C. Lammers, J.C. and Vaara, E. (2015), 'Putting Communication Front and Center in Institutional Theory and Analysis', Academy of Management Review, 40 (1), pp. 10-27. 
Cornelissen, J.P. and Clarke, J.S. (2010), 'Imagining and Rationalizing Opportunities: Inductive Reasoning and the Creation and Justification of New Ventures', Academy of Management Review, 35 (4), pp. 539-57.

De Ville, F. and Orbie, J. (2014). 'The European Commission's Neoliberal Trade discourse Since The Crisis: Legitimizing Continuity Through Subtle Discursive Change', The British Journal of Politics and International Relations, 16 (1), pp. 149-67.

Duina, F. and Bok, J. (2014), 'Capitalising on Regional Integration: Sub-national Movements and the Rhetorical Leveraging of NAFTA and the EU', New Political Economy, 19 (5), pp. 748-68.

Eckhardt, J. and Poletti, A. (2016), 'The Politics of Global Value Chains: ImportDependent Firms and EU-Asia Trade Agreements', Journal of European Public Policy, 23 (10), pp. 1543-62.

Eurostat. (2016), EU27 Manufacturing Exports to China. Available from: http://ec.europa.eu/eurostat/ [accessed 9 May 2016].

Evans, J. and Mavondo, F.T. (2002), 'Psychic Distance and Organizational Performance: An Empirical Examination of International Retailing Operations', Journal of International Business Studies, 33 (3), pp. 515-32.

Fligstein, N. (2001), 'Social Skill and the Theory of Fields', Sociological Theory, 19 (2), pp. 105-25.

Godden, D.M., and Walton, D. (2007). A theory of presumption for everyday argumentation. Pragmatics \& Cognition, 15 (2), 313-46.

Goff, P. (2008), 'Big Export Opportunities for Innovative NZ Companies', Speech at the New Zealand Government. Available from: https://www.beehive.govt.nz/speech/big-export-opportunities-innovative-nzcompanies [accessed 4 April 2016].

Green Jr, S.E. and Li, Y. (2011), 'Rhetorical Institutionalism: Language, Agency, and Structure in Institutional Theory since Alvesson 1993', Journal of Management Studies, 48 (7), pp. 1662-97.

Groser, T. (2012), 'Growing our Exports and the Role of China', Speech to the North Harbour China Business Panel. Available from: http://www.scoop.co.nz/stories/PA1203/S00214/groser-growing-our-exportsand-the-role-of-china.htm [accessed 4 April 2016]. 
Groser, T. (2013), 'Hon Tim Groser Address', Speech at the China Business Summit. Available from: https://itsourfuture.org.nz/hon-tim-groser-address-chinabusiness-summit [accessed 4 April 2016].

Hall, P.A. and Thelen, K. (2009), 'Institutional Change in Varieties of Capitalism', Socio-economic Review, 7 (1), pp. 7-34.

Harvey, D. (2007), A Brief History of Neoliberalism (USA: Oxford University Press). Hay, C. (2006). Constructivist institutionalism. In The Oxford Handbook of Political Institutions, ed. RAW Rhodes, S Binder, B Rockman, pp. 56-74. Oxford, UK: Oxford Univ. Press

Hay, C. and Rosamond, B. (2002), 'Globalization, European Integration and The Discursive Construction of Economic Imperatives', Journal of European Public Policy, 9 (2), pp. 147-67.

Hay, C. and Wincott, D. (1998), ‘Structure, Agency and Historical Institutionalism', Political studies, 46 (5), pp. 951-57.

Hoefer, R.L. and Green, S.E. (2016), 'A Rhetorical Model of Institutional Decision Making: The Role of Rhetoric in the Formation and Change of Legitimacy Judgments', Academy of Management Review, 41 (1), pp. 130-50.

Jennings, P.D. and Greenwood, R. (2003), 'Constructing the Iron Cage: Institutional Theory and Enactment', in R. Westwood and S. Clegg (eds), Debating Organization: Point-counterpoint in Organization Studies (Malden, MA: Blackwell Publishing), pp. 195-207.

Johanson, J. and Vahlne, J.E. (2009), 'The Uppsala Internationalization Process Model Revisited: From Liability of Foreignness to Liability of Outsidership', Journal of International Business Studies, 40 (9), pp. 1411-31.

Key, J. (2009), 'New Zealand and China: Our Shared Economic Future', Speech at Peking University. Available from: https://www.beehive.govt.nz/speech/speechnew-zealand-and-china-our-shared-economic-future [accessed 4 April 2016].

Kneller, R., Morgan, C.W., and Kanchanahatakij, S. (2008), 'Trade Liberalisation and Economic Growth', The World Economy, 31 (6), pp. 701-19.

Lee, D. and Nicki S. (2010), 'Small State Discourses in the International Political Economy', Third World Quarterly, 31 (7), pp. 1091-105. 
Liesch, P.W. and Knight, G.A. (1999), 'Information Internalization and Hurdle Rates in Small and Medium Enterprise Internationalization', Journal of International Business Studies, 30 (2), pp. 383-394.

Lush, M. (2010), 'John Key Calls for New Zealanders to Learn Mandarin', Radio Live, 12 July. Available from: http://www.radiolive.co.nz/John-Key-calls-for-NewZealanders-to-learn-Mandarin/tabid/506/articleID/14646/Default.aspx [accessed 10 April 2016].

Martin, J. (2015), 'Situating speech: A rhetorical approach to political strategy', Political Studies, 63 (1), pp. 25-42.

MBIE (2013), Small and Medium Sized Enterprises. Ministry of Business, Innovation and Employment (MBIE). Available from: http://www.mbie.govt.nz/business/business-growth-internationalisation/smalland-medium-sized-enterprises [accessed 13 June 2013].

Meunier, S. (2007), 'Managing Globalization? The EU in International Trade Negotiations', Journal of Common Market Studies, 45 (4), pp. 905-26.

Meyer, J.W. and Rowan, B. (1977), 'Institutionalized Organizations: Formal Structure as Myth and Ceremony', American Journal of Sociology, 83 (2), pp. 340-63.

MFAT. (2008a), Free Trade Agreement between the Government of New Zealand and the Government of the People's Republic of China (Wellington: MFAT). Available from: https://www.mfat.govt.nz/assets/FTAs-agreements-inforce/China-FTA/NZ-ChinaFTA-Agreement-text.pdf [accessed 19 May 2016].

MFAT. (2008b), NZ China FTA National Interest Analysis (Wellington: MFAT). Available from: https://www.mfat.govt.nz/assets/FTAs-agreements-inforce/China-FTA/National-interest-analysis.pdf [accessed 19 May 2016].

MFAT. (2017), NZ-China FTA Upgrade (Wellington: MFAT). Available from: https://www.mfat.govt.nz/en/trade/free-trade-agreements/free-trade-agreementsin-force/nz-china-free-trade-agreement [accessed 19 May 2017].

MFAT. (2019a), Free trade agreements (Wellington: MFAT). Available from: https://www.mfat.govt.nz/en/trade/free-trade-agreements/ [accessed 14 June 2019].

MFAT. (2019b). New Zealand-China FTA overview. Available from: https://www.mfat.govt.nz/en/trade/free-trade-agreements/free-trade-agreementsin-force/china-fta/nz-china-fta-overview/ 
Morin, J.F. and Carta, C. (2014), 'Overlapping and evolving European discourses on market liberalization', The British Journal of Politics and International Relations, 16 (1), pp. 117-32.

New Zealand Government (2013), Follow-up Review of New Zealand Trade and Enterprise (NZTE). Available from: https://www.nzte.govt.nz//media/NZTE/Downloads/About-us/PIF-reviews/NZTE-PIF-Follow-up-ReviewJune-2013.pdf [accessed 05 April 2019].

NZ Herald. (2013), 'Key urges kids to learn Mandarin', NZ Herald, 10 April. Available from:

http://www.nzherald.co.nz/nz/news/article.cfm?c_id=1\&objectid=10876524 [accessed 10 April 2016].

NZTE. (2011), Annual Report 2010/11 (Wellington: NZTE). Available from: https://www.nzte.govt.nz/-/media/NZTE/Downloads/About-us/Annualreports/Annual-Report-2010-2011.pdf [accessed 25 May 2016].

NZTE. (2012), Navigating China - For New Zealand Businesses (Wellington: NZTE). Available from: https://www.newzealandtradeenterprise.govt.nz/media/894196/navigating-china-2012.pdf [accessed 25 May 2016].

NZTE. (2013), How We Help New Zealand Business (Wellington: NZTE). Available from http://www.nzte.govt.nz/en/how-nzte-can-help/how-we-help-new-zealandbusiness/ [accessed 13 August 2013].

NZTE and MFAT. (2012), NZ Inc China Strategy: Opening Doors to China - New Zealand's 2015 Vision, NZTE Road Show presentation. Available from: https://www.tpk.govt.nz/_documents/nz-inc-china-strategy.pdf [accessed 13 August 2013].

Obokoh, L.O. (2008), 'Small and Medium Sized Enterprises Development under Trade Liberalisation: A Survey of Nigerian Experience', International Journal of Business and Management, 3 (12), pp. 92-101.

OECD. (1989), Economic Survey: New Zealand 1988/89 (Paris: OECD).

OECD. (1997), Globalisation and Small and Medium Enterprises (SMEs) (Paris: OECD). 
Pavcnik, N. (2002), 'Trade Liberalization, Exit, and Productivity Improvements:

Evidence from Chilean Plants', Review of Economics Studies, 69 (1), pp. 24576.

Peres, W. and Stumpo, G. (2000), 'Small and Medium-Sized Manufacturing Enterprises in Latin America and the Caribbean under the New Economic Model', World Development, 28 (9), pp. 1643-55.

Pierson, P. (2000), 'The Limits of Design: Explaining Institutional Origins and Change', Governance, 13 (4), pp. 475-99.

Pula, B. (2018), 'What Makes Firms Competitive? States, Markets, and Organisational Embeddedness in Competitive Firm Restructuring in Postsocialist Economies', New Political Economy, 23 (4), pp. 458-74.

Rao, H., Monin, P., and Durand, R. (2003), 'Institutional Change in Toque Ville: Nouvelle Cuisine as an Identity Movement in French Gastronomy', American Journal of Sociology, 108 (4), pp. 795-843.

Schmidt, V. A. (2008), 'Discursive institutionalism: The explanatory power of ideas and discourse.', Annual Review of Political Science, 11 (1), 303-326.

Schmidt, V. A. (2003), 'How, Where and When does Discourse Matter in Small States' Welfare State Adjustment?', New Political Economy, 8 (1), pp. 127-46.

Shane, S. (2009), 'Why Encouraging More People to Become Entrepreneurs is Bad Public Policy', Small Business Economics, 33 (2), pp. 141-49.

Siles-Brügge, G. (2011), 'Resisting protectionism after the crisis: Strategic economic discourse and the EU-Korea free trade agreement', New Political Economy, 16 (5), pp. 627-53.

Statistics New Zealand. (2013), Global New Zealand - International trade, Investment, and Travel profile, Year ended June 2012. Available from: http://www.stats.govt.nz/browse_for_stats/industry_sectors/imports_and_export s/global-nz-jun-12.aspx on 14 June 2013 [accessed 9 May 2016].

Streeck, W. and Thelen, K.A. (2005), 'Introduction: Institutional Change in Advanced Political Economies', in W. Streeck and K.A. Thelen (eds), Beyond Continuity: Institutional Change in Advanced Political Economies (New York: Oxford University Press), pp. 1-39. 
Tambunnan, T. (2008), 'Trade Liberalization Effects on the Development of Small and Medium-Sized Enterprises in Indonesia: A Case Study', Asia-Pacific Development Journal, 15 (2), pp. 35-59.

US Census Bureau. (2016), Trade in Goods with China. Available from: https://www.census.gov/foreign-trade/balance/c5700.html [accessed 9 May 2016].

Walter, R. (2017), 'Rhetoric or Deliberation? The case for rhetorical political analysis', Political Studies, 65 (2), pp. 300-315.

Watson, M. and Hay, C. (2003), 'The discourse of globalisation and the logic of no alternative: rendering the contingent necessary in the political economy of New Labour', Policy \& Politics, 31 (3), pp. 289-305.

Werner, M.D. and Cornelissen, J.P. (2014), 'Framing the Change: Switching and Blending Frames and Their Role in Instigating Institutional Change', Organization Studies, 35 (10), pp. 1449-72.

Wilkinson, R. (2009), Language, power and multilateral trade negotiations. Review of International Political Economy, 16(4), pp. 597-619.

World Bank. (2016), Imports of Goods and Services (current US\$). Available from: https://data.worldbank.org/indicator/NE.IMP.GNFS.CD?locations=CN [accessed 9 May 2016]. 
Table 1. Company and manager/owner/founder participant profiles

\begin{tabular}{|c|c|c|c|}
\hline Company profile & Rounded \% & Participant profile & Rounded \% \\
\hline Number of employees: & & Role: & \\
\hline Fewer than 20 employees & $8(22)$ & $\mathrm{CEO} / \mathrm{GM}$ & $17(47)$ \\
\hline 20-250 employees & $23(64)$ & Owner/(Co)-founder & $15(42)$ \\
\hline More than 250 employees & $5(14)$ & $\begin{array}{l}\text { International/Asia } \\
\text { manager }\end{array}$ & $4(11)$ \\
\hline Age of the business: & & Gender: & \\
\hline Founded 2000 or later & $11(31)$ & Male & $34(94)$ \\
\hline Founded from 1980 to 1999 & $11(31)$ & Female & $2(5)$ \\
\hline Founded from 1950 to 1979 & $8(22)$ & & \\
\hline Founded before 1950 & $6(17)$ & & \\
\hline \multicolumn{4}{|l|}{ Nature of the business: } \\
\hline Food product manufacturing & $8(22)$ & & \\
\hline Machinery and equipment manufacturing & $9(25)$ & & \\
\hline $\begin{array}{l}\text { Basic chemical and chemical product } \\
\text { manufacturing }\end{array}$ & $6(17)$ & & \\
\hline $\begin{array}{l}\text { Beverage and tobacco product } \\
\text { manufacturing }\end{array}$ & $3(8)$ & & \\
\hline Furniture and other manufacturing & $2(5)$ & & \\
\hline Other & $8(22)$ & & \\
\hline \multicolumn{4}{|l|}{ Location: } \\
\hline Auckland & $23(64)$ & & \\
\hline Christchurch & $4(11)$ & & \\
\hline Wellington & $4(11)$ & & \\
\hline Other (North Island) & $2(5)$ & & \\
\hline Other (South Island) & $3(8)$ & & \\
\hline
\end{tabular}

